\title{
Reproductive biology of Caspian vimba, Vimba vimba (L.), in the coastal waters of the southwestern Caspian Sea
}

\author{
Fateme Tari, Javid Imanpour Namin, Shahram Abdolmalaki, Mahvash Hadavi
}

Received - 19 January 2015/Accepted - 28 August 2015. Published online: 31 October 2015; @Inland Fisheries Institute in Olsztyn, Poland Citation: Tari F., Namin J.I., Abdolmalaki S., Hadavi M. 2015 - Reproductive biology of Caspian vimba, Vimba vimba (L.), in the coastal waters of the southwestern Caspian Sea - Arch. Pol. Fish. 23: 171-180.

\begin{abstract}
The reproduction biology of Caspian vimba, Vimba vimba (L.), was investigated on the southwestern coast of the Caspian Sea using 712 fish specimens collected at three fisheries catch stations located in Talesh, Anzali, and Kiashahr over a two-year period from April 2012 through June 2013. Seasonal changes in the gonadosomatic index, gonad histological status, size frequency distribution of oocytes, and the fecundity of the species were studied. The peaks of the gonadosomatic index (GSI) were observed both in females and males in June 2012 and May 2013 indicating the variable peak spawning time of this species. Histological examinations and oocyte frequency distribution patterns showed synchronous oocyte development in the Caspian vimba. Absolute fecundity ranged from 5873 to 35421 eggs. The size at first maturity for females was $120 \mathrm{~mm}$ FL. We concluded that the Caspian vimba is a total spawner with variable spawning dependent on environmental factors.
\end{abstract}

Keywords: Caspian Sea, Vimba vimba, gonadosomatic index, fecundity, oocyte development

F. Tari, J. Imanpour Namin [ $\left.\Xi^{\circ}\right]$

Department of Fisheries, Faculty of Natural Resources

University of Guilan, Sowmeh-Sara, Iran

e-mail: imanpour@guilan.ac.ir

\section{S. Abdolmalaki}

International Research Institute for Sturgeon Fishes

Rasht, Guilan, Iran

M. Hadavi

Department of Biology, Faculty of science, University of Guilan, Rasht, Iran

\section{Introduction}

Reproductive strategy is a fundamental topic in the study of population dynamics and the biology of fish species (Hunter et al. 1992, Murua and Sabrido-Ray 2003). Successful fisheries management must consider the reproductive ability of fish populations and assess accurately biological parameters including reproductive characteristics, such as spawning season duration, fish age and size at maturity, and fecundity along with growth and mortality estimates (Quinn and Deriso 1999). Moreover, determining spawning patterns is necessary to acquire an understanding of the population dynamics of different fish species (Hilborn and Walters 1992, Rinchard and Kestemont 2003). Reproduction studies provide basic quantitative data on reproductive capacity that are used to assess the effects of exploiting fish populations (Murua 2010). Finally, knowledge about fish reproductive processes at cellular levels is critical for the proper management of fish species rehabilitation (Jakobsen et al. 2009). Fish reproduction is a periodic process (Munro 1990) that is reflected in gonad weight, fecundity, and oocyte development (Narimatsu et al. 2005). Abiotic and biotic factors can cause variations in reproductive traits such as reproductive strategy, fecundity, and gonad weight (Fowler et al. 2000), and these factors are capable of

\footnotetext{
C Copyright by Stanisław Sakowicz Inland Fisheries Institute in Olsztyn.

(c) 2015 Author(s). This is an open access article licensed under the Creative Commons Attribution-NonCommercial-NoDerivs License (http://creativecommons.org/licenses/by-nc-nd/3.0/).
} 


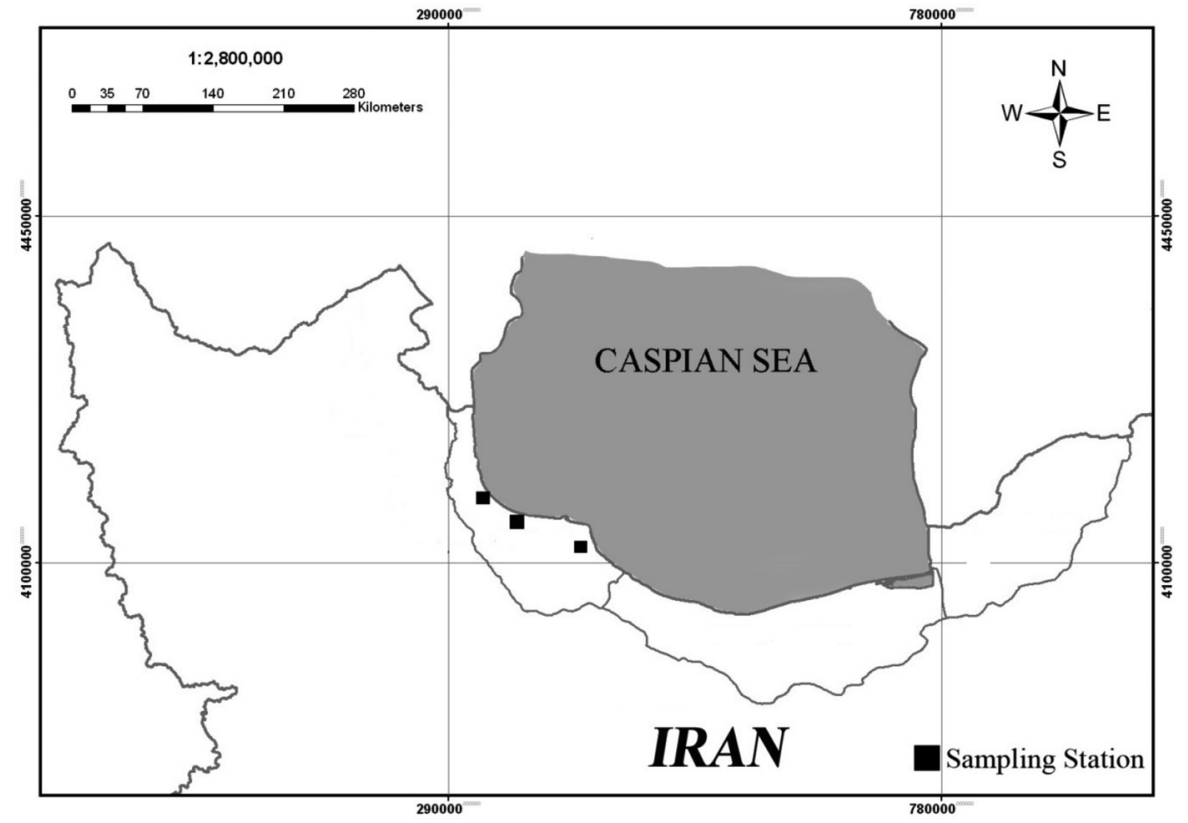

Figure 1. Map of the southern coast of the Caspian Sea. Rectangles represent sampling sites of V. vimba.

influencing reproductive ability (Marshall et al. 1998).

Several commercially important fishes inhabit the Caspian Sea (Chaichi et al. 2011) including the cyprinid species Vimba vimba (L.). Vimba is a migratory fish that mainly lives in fresh as well as brackish waters. It migrates into fresh water in spring to reproduce, after which the spawners return to brackish waters to feed and prepare for the subsequent reproduction cycle (Hänfling et al. 2009). Under natural conditions, vimba attains maturity at the age of 4-5 years (Euszczek-Trojnar et al. 2008). Spawning occurs during May and July on gravel beds in fast flowing streams and rivers (Bontemps 1971).

Opinions about the reproductive strategy of vimba are varied. Kazancheev (1981) states that vimba is a total spawner, whereas Łuszczek-Trojnar et al. (2008) report that a total of 30000-120000 eggs can be deposited in two or three batches by vimba in Poland. A review of the literature on the reproduction biology of vimba reveals that several points require further study to gain a comprehensive understanding of the reproduction strategies of vimba on the southwestern coast of the Caspian Sea. To date, no histological studies have been performed on vimba reproductive parameters in this region of the Caspian Sea. Therefore, the decision was taken to tackle the question of whether vimba from the southwestern regions of the Caspian Sea is a batch or total spawner. For this purpose, size at maturity, gonad histology, trends in gonadosomatic index, fecundity, and oocyte diameter frequencies were examined to shed light on the reproductive biology of the species. This information is vital since vimba constitutes an important segment of commercial catches of teleost fishes in the southern basins of the Caspian Sea. Finally, the results obtained are crucial for developing preliminary stock rehabilitation and management measures.

\section{Materials and Methods}

\section{Sampling}

The study was conducted in the southern basin of the Caspian Sea. Locations of the sampling sites are presented in Fig. 1. A total of 712 specimens (343 female, 369 male) was collected randomly from April 2012 through June 2013 - a period that covered two consecutive vimba spawning seasons. Sampling was performed monthly. 
Gill nets with a mesh size range of 9-28 mm were used for sampling by commercial fishermen in three fishing zones including Kiashhr $\left(37^{\circ} 25^{\prime} 10^{\prime \prime} \mathrm{N}, 49^{\circ} 56^{\prime} 56^{\prime \prime} \mathrm{E}\right)$, Bandar Anzali $\left(37^{\circ} 28^{\prime} 0.12^{\prime \prime} \mathrm{N}, \quad 49^{\circ} 28^{\prime} 0.12^{\prime \prime}\right)$, and Talesh ( $37^{\circ} 46^{\prime} 54.63^{\prime \prime} \mathrm{N}, 48^{\circ} 56^{\prime} 36.64^{\prime \prime} \mathrm{E}$ ) along the southern coast of the Caspian Sea.

\section{General biological data and determining spawning time}

The fork lengths (FL, mm), total weights (TW, g) $( \pm 1$ $\mathrm{g})$, and gonad weights $(\mathrm{GW})( \pm 0.001 \mathrm{~g})$ of all specimens were measured. Sex was determined by examining the gonads in the laboratory, and the macroscopic maturity stages were recorded based on the criteria outlined in Table 1.

The following formula was used to estimate the gonadosomatic index (GSI) of each fish with intact gonads (Brown-Peterson et al. 2001)

$$
G S I=\frac{G W}{T W-G W} \times 100
$$

where GW is gonad weight, and TW is total weight.

\section{Histological analysis and size-frequency distribution}

Histological analysis was conducted to determine maturity stages at the microscopic level to assist in determining the reproductive strategy of $V$. vimba. The ovaries were removed from a sub-sample of 150 females collected during the reproductive period. The gonads were weighed $( \pm 0.001 \mathrm{~g})$, and the right lobes of the ovaries were preserved in $10 \%$ buffered formaldehyde. Tissue samples were taken transversely to avoid possible discrepancies in the developmental stage of oocytes because of their position in the ovary. Histological slides were prepared by dehydrating samples in $70 \%$ ethanol, and then, according to routine procedures, the samples were embedded in paraffin and $5 \mu \mathrm{m}$ sections were cut and then stained with hematoxylin and eosin. The histological classification of oocytes (Table 1) was done according to Brown-Peterson et al. (2011). Intact ovaries from ten females at each phase of maturity were used to determine the oocyte size-frequency distribution. Samples were placed in Petri dishes and separated using a needle, and the diameters of 100 to 300 oocytes were measured under a stereo-microscope (Olympus SZX12, USA) using transmitted light and bright-field illumination to determine each maturity stage. Oocyte developmental stages were classified as choromatin nucleolar, perinucleolar, cortical alveoli, vitellogenic yolk, and nucleolar migration (Davis and West 1993). Only those oocytes that were sectioned through the nucleus were included in size frequency analyses. Fecundity was estimated using 24 female fish sampled from March to June 2013.

Table 1

Macroscopic and histological staging criteria for the ovary of vimba, modified criteria by Brown-Peterson et al. (2011)

\begin{tabular}{lll}
\hline \hline Phase & Macroscopic appearance & Histological features \\
\hline \hline I. Immature & $\begin{array}{l}\text { Small ovary and blood vessels } \\
\text { indistinct }\end{array}$ & $\begin{array}{l}\text { Only oogonia and primary growth (PG) oocytes present, no atresia } \\
\text { present } \\
\text { Early vitellogenesis: Vtg1 and Vtg2, PG, cortical alveoli (CA) present. }\end{array}$ \\
$\begin{array}{ll}\text { II. Developing: includes early } \\
\text { developing sub-phase }\end{array}$ & Enlarging ovary & $\begin{array}{l}\text { In early developing sub-phase PG oocytes and CA only present } \\
\text { Late vitellogenesis: Vtg3 oocytes present. In actively spawning }\end{array}$ \\
actively spawning sub-phase & $\begin{array}{l}\text { Large ovary, blood vessels } \\
\text { prominent }\end{array}$ & $\begin{array}{l}\text { sub-phase late oocyte with nuclear migration, hydration or ovulation } \\
\text { present }\end{array}$ \\
IV. Regressing & Flaccid ovary & $\begin{array}{l}\text { Post ovulatory follicles (POFs) and atresia present. Some CA or Vtg1 } \\
\text { and Vtg2 present }\end{array}$ \\
V. Regenerating & Small ovary & Oogonia and PG present. Old atresia and POFs may be present
\end{tabular}




\section{Fecundity}

To investigate the effect of ovary region on oocyte number, $0.15 \mathrm{~g}$ oocyte samples were taken from the anterior, middle, and posterior parts of both left and right ovaries of ten females (Dominguez-Petit 2006). Fish with intact ovaries in phase III, which is defined as spawning capable according to Brown-Peterson et al. (2011), and without signs of postovulatory follicles (POF) were used for fecundity estimations (Ganias et al 2004). No significant differences were noted in the numbers of oocytes among the three sections of each ovary $(\mathrm{F}=0.057, \mathrm{df}=2, \mathrm{P}>0.05)$ nor between the left and right ovaries $(\mathrm{F}=0.004, \mathrm{df}=1, \mathrm{P}$ $>0.05)$. Therefore, $0.15 \mathrm{~g}$ oocyte samples collected from the middle part of the right ovary were used to estimate fecundity. Absolute fecundity was determined by multiplying the oocyte number per $0.15 \mathrm{~g}$ of ovary by the gonad weight. A power regression was fitted to determine the relationship between fish fork length and absolute fecundity. Relative fecundity was estimated using the following formula: $\mathrm{RF}=\mathrm{AF} \times$ $\mathrm{BW}^{-1}$, where $\mathrm{AF}$ is absolute fecundity, and $\mathrm{BW}$ is body weight (g).

\section{Size at maturity}

A sample of 137 females 8-20 cm FL were used to estimate size at maturity in the 2013 spawning season (March to June 2013). Fish were considered mature when oocytes were in late vitellogenesis or in phases III-V based on macroscopic criteria (Table 1). Fish length was classified into $10 \mathrm{~mm}$ categories, and the logistic model fitted to the data was as follows:

$$
P=1 /\left(1+e^{-r\left(L-L_{m}\right)}\right)
$$

where $r$ is the slope of the curve, and $L_{m}$ is the length at sexual maturity or the length corresponds of 0.5 (or 50\%) in reproductive condition.

\section{Statistical analysis}

Data are presented as means \pm standard error (SE). Two-way analysis of variance (ANOVA) was used to understand the interaction of gender and month as independent factors on GSI, and the Duncan test was used to establish monthly differences in genders. One way ANOVA was used to compare the number of oocytes in the three sections of each ovary, and in the right and left ovaries. Linear regression was applied to observe the relationship between FL and fecundity. Statistical analyses were performed using SPSS (Version 16, Inc., Chicago, IL, USA). The level of significance for data analyses was 0.05 .

\section{Results}

\section{Biological Data and Spawning Time}

The fork lengths of the females and males used in the study ranged from 8 to $21.4 \mathrm{~cm}$ and from 8 to 20.3 $\mathrm{cm}$, respectively. Significant differences were observed in the length frequency distribution between females and males $\left(\chi^{2}=58.25\right.$, $\left.\mathrm{df}=12, \mathrm{P}<0.05\right)$. The chi square $\chi^{2}$-test indicated that the sex ratio was not significantly different from the theoretical 1:1 sex ratio $\left(\chi^{2}=0.94, \mathrm{df}=1, \mathrm{P}>0.05\right)$. Females constituted $48 \%(n=343)$ and males $52 \%$ of the samples. As shown in Figure 2, the frequency of males was notably higher than females in 2012 and 2013. The combination of gender and month affected changes in GSI significantly $\left(\mathrm{F}_{\text {Sex }}{ }^{* \text { Month }}=13.43, \mathrm{df}=13, \mathrm{P}<\right.$ 0.05). In both sexes, the GSI index increased gradually from April 2012 and peaked in June 2012, when the mean value was 13.59 for females and 5.05 for males; whereas in 2013, the pattern started in March and reproductive activity peaked in May when the mean GSI was 6.03 for males and 10.19 for females (Fig. 3).

\section{Histological analysis and size-frequency distribution}

The oocyte development pattern of vimba from the coastal waters of the southwestern Caspian Sea was synchronous. Predominantly, oocyte development was synchronous at all phases of gonad development 


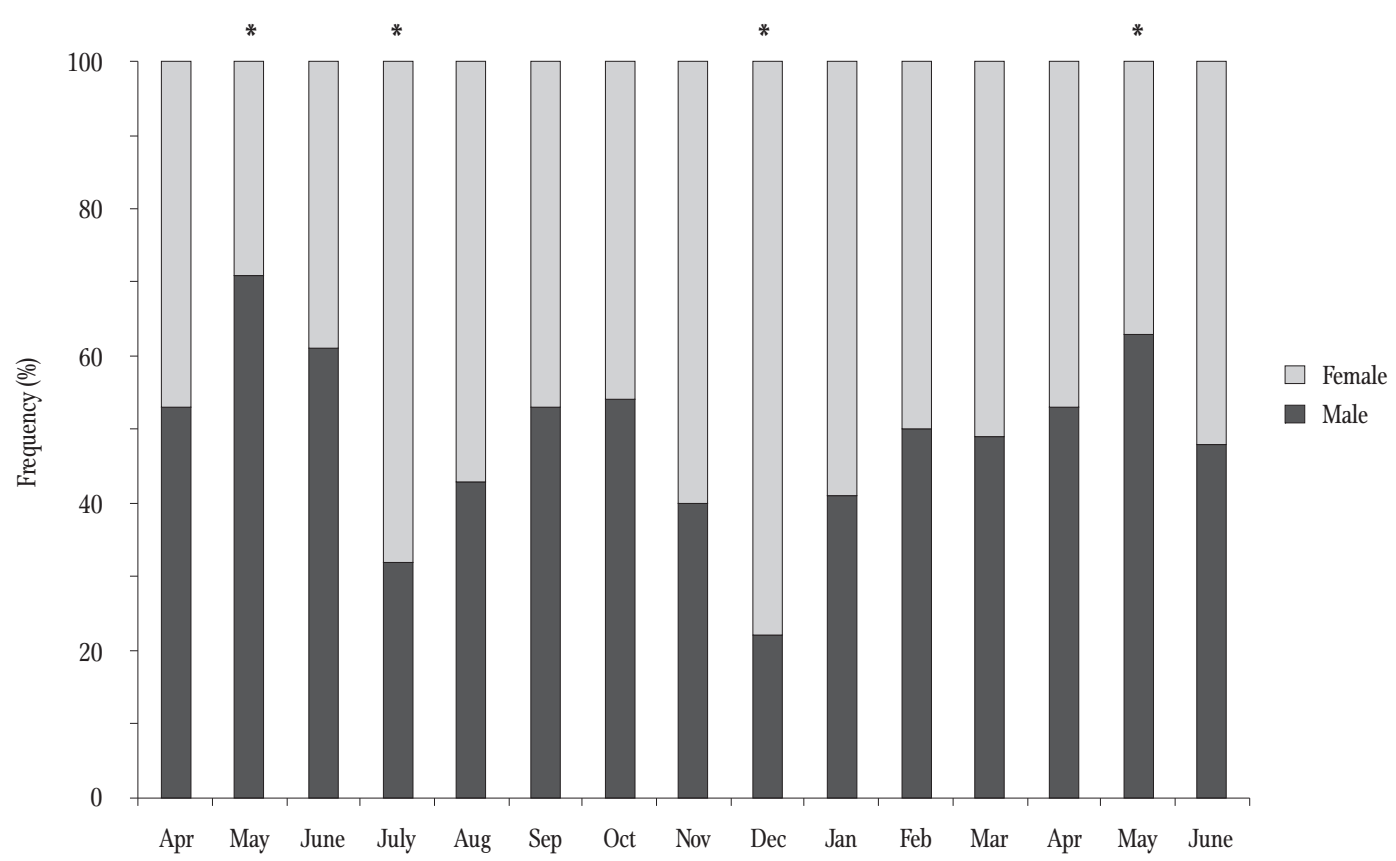

Figure 2. Monthly percent frequency of both sexes of $V$. vimba from April 2012 to June 2013 in the coastal waters of the southwestern Caspian Sea. * indicates significant difference from the theoretical 1:1 sex ratio.

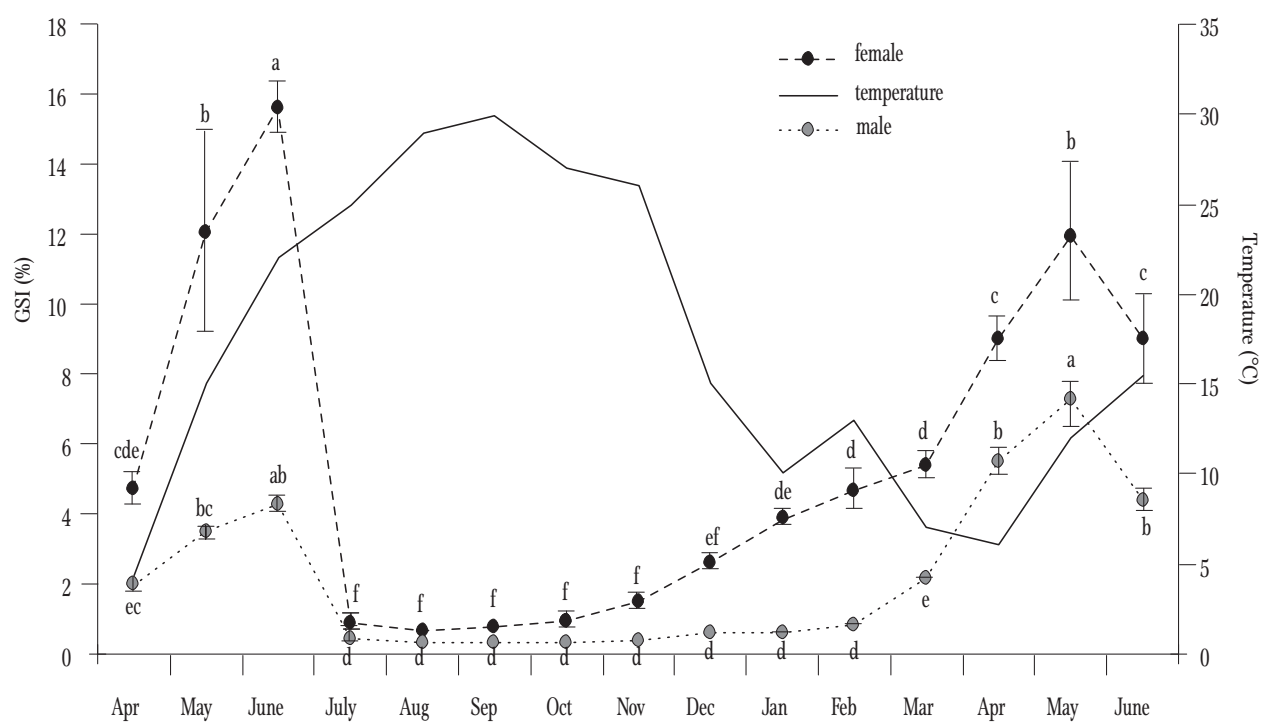

Figure 3. Monthly changes in the gonadosomatic index of $V$. vimba and the average water surface temperatures in the coastal waters of the southwestern Caspian Sea.

(Fig. 4). There was no evidence of post-ovulatory follicles (POFs) in ovaries in the active spawning sub-phase (Fig. 5), indicating that vimba is a total spawner in this region. The examination of oocyte diameter distributions indicated egg diameter below $240 \mu \mathrm{m}$ (Fig. 4) in the early developmental sub-phase, which was dominated by choromatin nucleolar, perinucleolar, and cortical alveoli (Fig. 5). At the beginning of vitellogenesis, oocyte diameter increased (260-440 $\mu \mathrm{m}$ ) (Fig. 4) because of the occurrence of early vitellogenesis (Vtg1 and Vtg2) (Fig. 5). The phase of late vitellogenesis (Vtg3) and large nucleus-migrated oocytes resulted in a significant increase in egg diameter (500-980 $\mu \mathrm{m})$ (Fig. 4). 

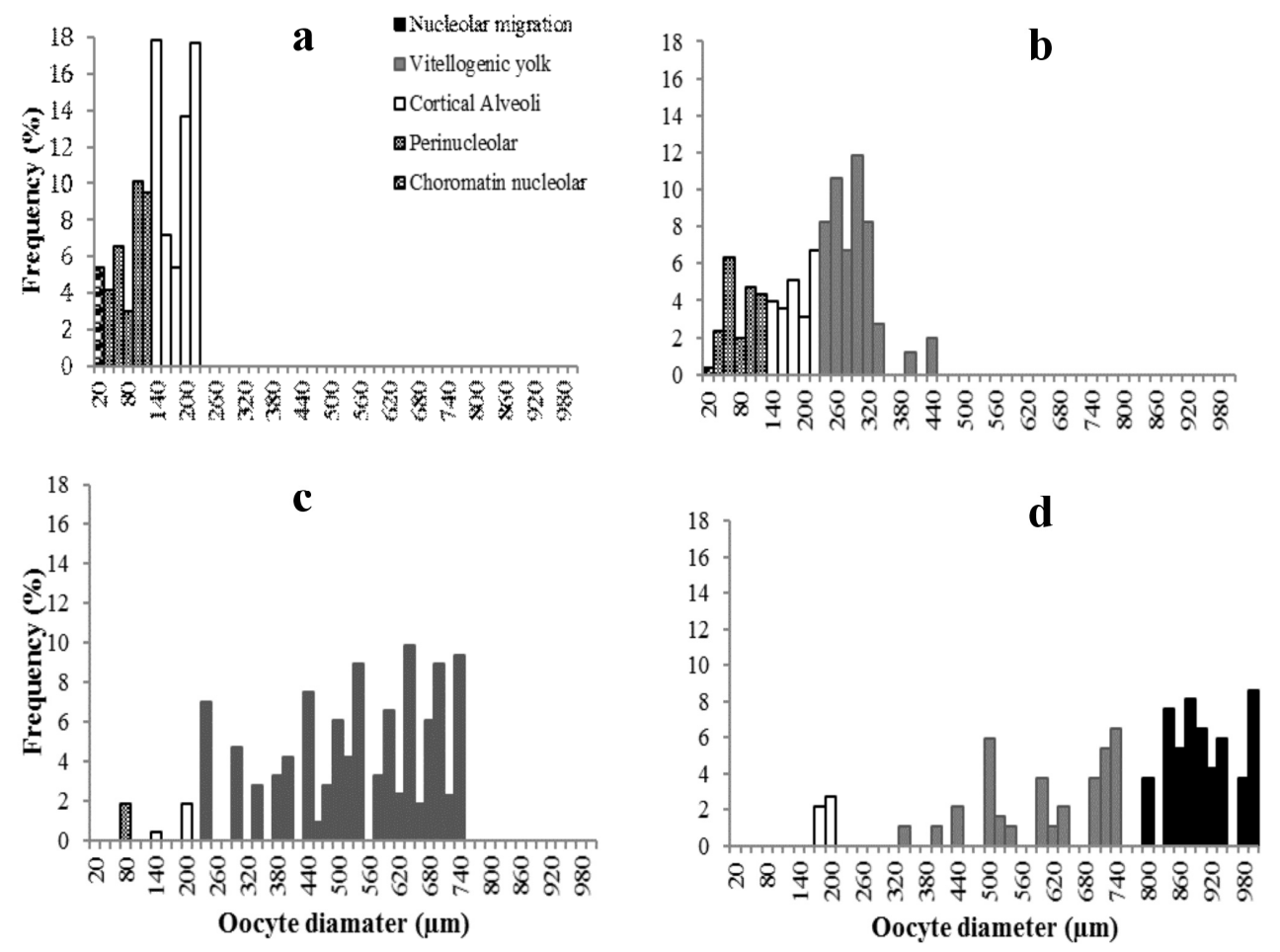

Figure 4. Size frequency distribution of oocyte diameter of $V$. vimba. A) phase II, early developing sub-phase, B) phase II, C) phase III, D ) phase III, actively spawning sub-phase. $n=10$ for each phase.

\section{Fecundity}

No significant difference was noted between the weight of the right and left ovaries in the sub-sample of 20 females that were tested using the t-test presuming equal variance $(\mathrm{t}=-0.112, \mathrm{df}=38, \mathrm{P}>0.05)$. Mean relative fecundity was $934 \pm 68(\mathrm{SE})$, and ranged from 410 to 1771 . Absolute fecundity (the number of mature oocytes per gram of fish body weight) was $15822 \pm 157$ ranging from 5873 (for an individual with a fork length of $143 \mathrm{~mm}$ and a weight of $33.5 \mathrm{~g}$ ) to 35421 (for an individual with a fork length of $200 \mathrm{~mm}$ and a weight of $118.8 \mathrm{~g}$ ). The relation between FL and fecundity was positive and significant $\left(\mathrm{r}^{2}=0.79, \mathrm{df}=23, \mathrm{P}<0.05\right)$ (Fig. 6) and was defined by the following equation: $\mathrm{Fec}=3180.2 \times \mathrm{FL}$ $-36028$.

\section{Size at maturity}

The mean size at $50 \%$ maturity $\left(\mathrm{L}_{50}\right)$ was $120 \mathrm{~mm}$ (Fig. 7). All females were mature at $180 \mathrm{~mm} \mathrm{FL,} \mathrm{and}$ the fork length of the smallest mature female was $114 \mathrm{~mm}$ (Table 2).

Table 2

Number of mature fish in each length class within the sampled population of $V$. vimba in the coastal waters of the southwestern Caspian Sea

\begin{tabular}{llllllllllllllll}
\hline \hline & \multicolumn{1}{c}{ Length class $(\mathrm{cm})$} \\
\cline { 2 - 10 } & $8-9$ & $9-10$ & $10-11$ & $11-12$ & $12-13$ & $13-14$ & $14-15$ & $15-16$ & $16-17$ & $17-18$ & $18-19$ & $19-20$ & $20-21$ \\
\hline \hline $\begin{array}{l}\text { Number of mature } \\
\text { fish }\end{array}$ & 0 & 0 & 0 & 1 & 4 & 17 & 22 & 17 & 12 & 18 & 14 & 9 & 2 \\
\hline \hline
\end{tabular}



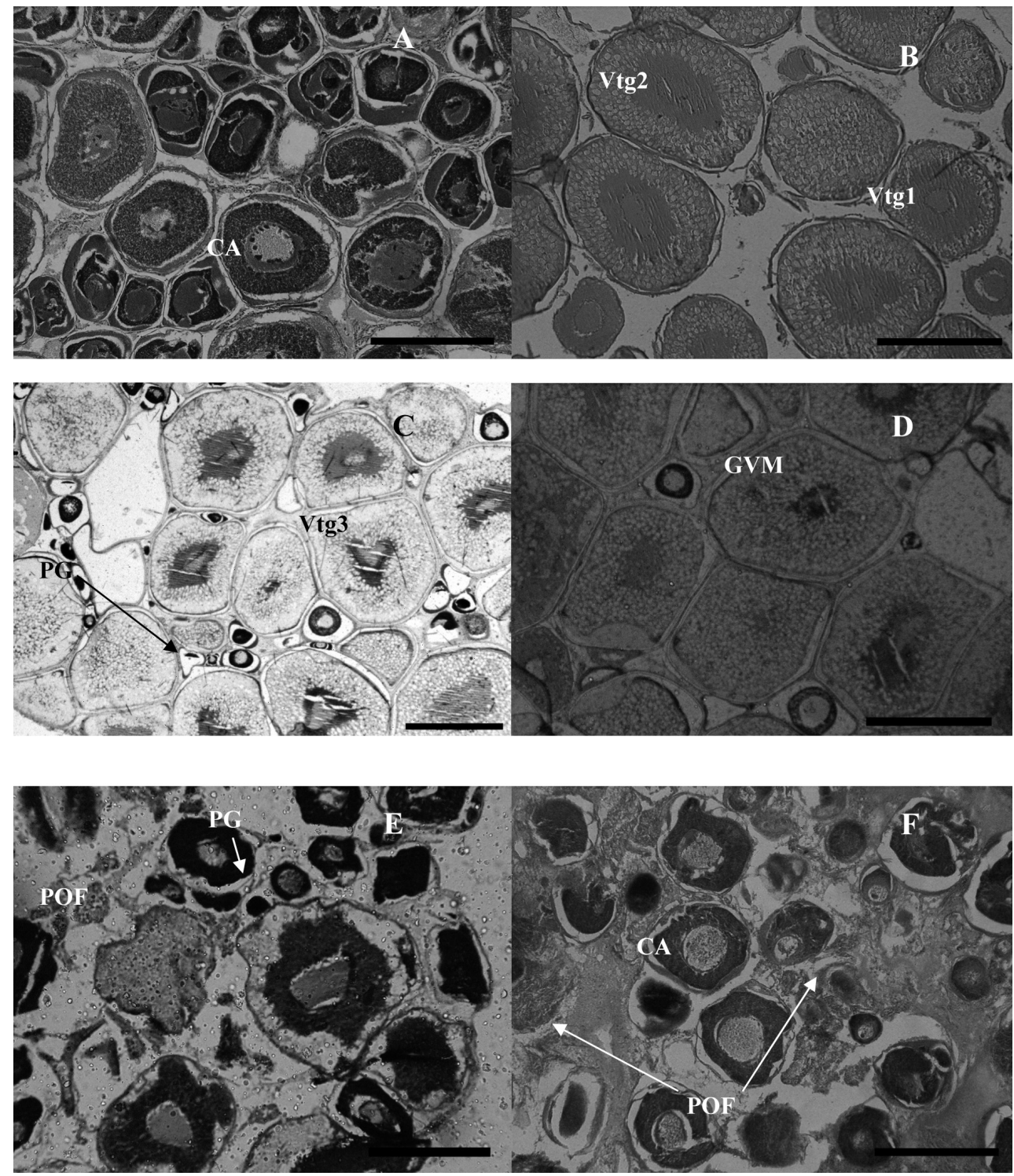

Figure 5. Histological sections of ovaries of V. vimba. A) early developing sub-phase, B) developing, C) spawning capable, D) late spawning capable sub-phase, E) regressing. F) regenerating. $\mathrm{PG}=$ Primary Growth, $\mathrm{CA}=$ Cortical Alveol, Vtg1 = Primar Vitellogenic Oocyte, Vtg2 = Secondary Vitellogenic Oocyte, Vtg3 = Tertiary Vitellogenic Oocyte, GVM = Germinal Vesicle Migration, POF = Postovulatory Follicle Complex. Scale bars $500 \mu \mathrm{m}$.

\section{Discussion}

A reliable method for estimating the duration of the reproductive season and the peak of spawning activity in many fish species is to combine the gonadosomatic index (GSI) with the proportion of various maturity phases (Fowler et al. 2000, Brown-Peterson et al. 2001, Lowerre-Barbieri et al. 2011). In this study, vimba exhibited inter-annual variation in the beginning and peak of spawning.
Previous studies on reproductive strategies of vimba also show a similar pattern. Schishabekov (1979) reported the onset of vimba spawning varies from one year to another under the influence of water temperature. Hosseini et al. (2010) reported the occurrence of adult vimba in Sefidroud River early in February indicating the early initiation of spawning. Different ecological and climatic conditions can affect the onset of vitellogenesis and the duration of spawning (Okgerman et al. 2011). The most significant 


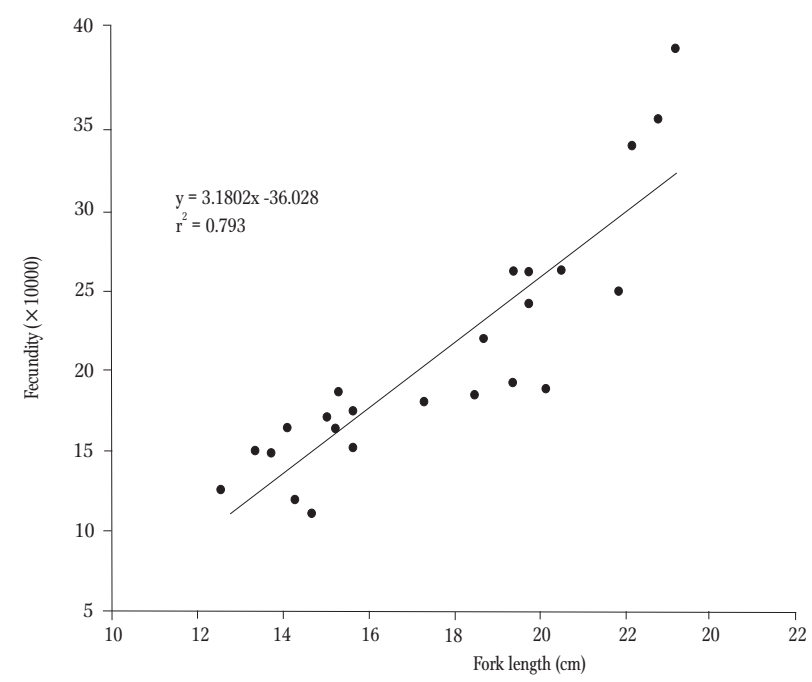

Figure 6. Relation between absolute fecundity and fork length $(\mathrm{mm})$ of $V$. vimba $(\mathrm{n}=24)$ in the coastal waters of the southwestern Caspian Sea.

environmental factor is water temperature, which can determine when the spawning period begins and also peak spawning (Wootton 1982, Lam 1983, Scott and Pankhurst 1992). Low water temperatures can influence vitellogenesis, and, consequently, delays in spawning can follow (Kjesbu 1994). In the present study, the mean water temperature $(9.35 \pm$ $2.19^{\circ} \mathrm{C}$ ) in February and March 2013 coincided with active vitellogenesis in vimba and also with the synchrony of the early onset of spawning as compared to 2012, when the mean water temperature in February and March 2012 was $6.6 \pm 0.55^{\circ} \mathrm{C}$. Fish species use a variety of reproductive strategies to increase offspring survival (Balon 1985). The following was noted in this study and could confirm synchronous oocyte development and total spawning in vimba: (i) the absence of post-ovulatory follicles (POFs) in ovaries in different stages except for their dominant presence in ovaries in the spent regressing stage; (ii) lack of oocytes in different developmental stages at the whole ovary phases; (iii) invariability of the GSI trend during the spawning season and the occurrence of only one peak; (iv) the presence of only one clutch of growing oocytes in the size-frequency distribution. In species with synchronous oocyte development, oocytes develop and the fish ovulate

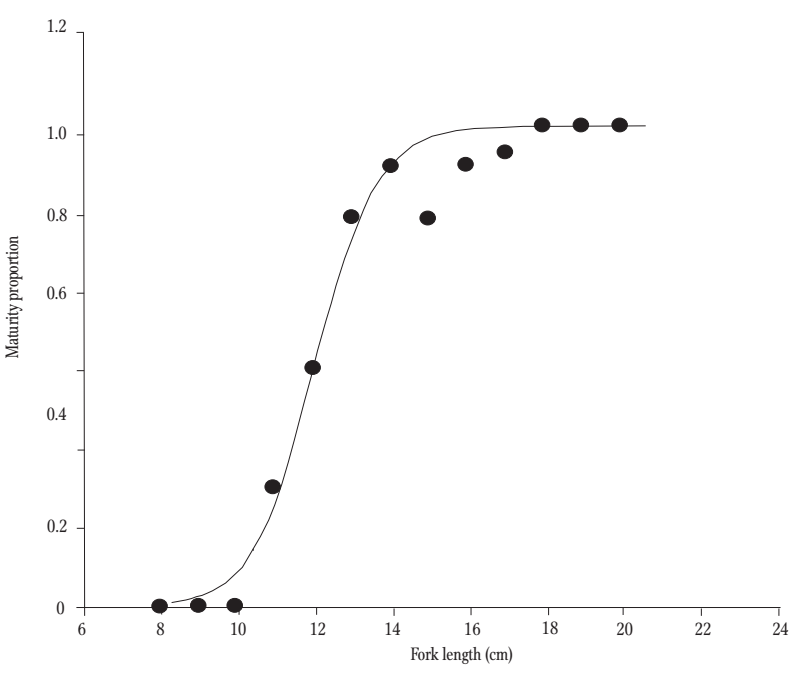

Figure 7. Proportion of mature female $V$. vimba at $10 \mathrm{~mm}$ length intervals. $n=137$ (116 mature) in the coastal waters of the southwestern Caspian Sea.

simultaneously, therefore, there is no replenishment from earlier stages (Wallace and Selman 1981, Murua and Saborido-Ray 2003). Species are known as total spawners when all clutches of yolked oocytes ovulate at one time and the eggs are shed over a short period or in a unique event (Tyler and Sumpter 1996). Obviously, vimba is a species with determinate fecundity, and during the spawning season increases in the mean diameter of advanced vitellogenic oocytes is expected. As the spawning season proceeds, the diameter of advanced yolked oocytes remains constant or decreases (Greer Walker et al. 1994). A previous study by Patimar and Safari (2010) on the biology of Caspian vimba reports a similar range and mean fecundity, with a range of absolute fecundity of 5436-36141 eggs for $3+$ to $5+$ fish (mean $16672 \pm 6902.7$ eggs) for vimba caught in the Miankaleh Wildlife Refuge. In the present study, a positive relationship was observed between length and absolute fecundity. Length at 50\% maturity was $120 \mathrm{~mm}$ smaller than the figure of $170 \mathrm{~mm}$ reported by Chaichi et al. (2011) from southeast Caspian Sea. A common response to environmental variations, which cause increased fish growth rates, is decreasing age and maturity size (Stearns and Crandall 1984). One of the main factors that could be 
responsible for decreasing size at maturity is fishing mortality, which can lead to reduced population sizes (Tripple 1995). Therefore, lower age and size at maturity force individuals to participate in one or two spawning season before they are caught (Cardinale and Modin 1999) in order to survive their generation.

Acknowledgments. The authors would like to thank staff of the Inland Water Aquaculture Research Institute for their support. Some parts of the present research were supported financially by the University of Guilan.

Author contributions. All authors conceived the study, performed the research, wrote the paper, and read the final manuscript.

\section{References}

Balon E.K. 1985 - Early life histories of fishes: new developmental ecological and evolutionary perspectives - Developments in Env. Biol. Fish. 5, Dr W. Junk Publishers, Dordrecht. 280 p.

Bontemps S. 1971 - Vimba - PWRiL, Warsaw. 216 p. (in Polish)

Brown-Peterson N.J., Overstreet R.M., Lotz J.M., Franks J.S., Burns K.M. 2001 - Reproductive biology of cobia, Rachycentron canadum, from coastal waters of the southern United States - Fish. Bull. 99: 15-28.

Brown-Peterson N.J., Wyanski D.M., Saborido-Ray F., Macewicz B.J., Lowerre-Barbieri S.K. 2011 - A standardized terminology for describing reproductive development in fishes - Mar. Coast. Fish. 3: 52-70.

Cardinale M., Modin J. 1999 - Changes in size-at-maturity of Baltic cod (Gadus morhua) during a period of large variations in stock size and environmental conditions - Fish. Res. 41: 285-295.

Chaichi A.R., Vosoughi G.H., Kaymaram F., Jamili S., Fazli H. 2011 - Reproduction characteristics of the Vimba vimba persa (Pallas, 1811) in coastal waters of the Caspian Sea - Iran. J. Fish. Sci. 10: 585-595.

Davis T.L.O., West G.J. 1993 - Maturation reproductive seasonality, fecundity, and spawning frequency in Lutjanus vittus (Quoy and Gaimard) from the North West Shelf of Australia - Fish. Bull. 91: 224-236.

Domínguez-Petit R. 2007 - Study of Reproductive Potential of Merluccius merluccius in the Galician Shelf - Doctoral Thesis, University of Vigo (Spain), 253 p.+ xxii.

Fowler A.J., Mcleay L., Short D.A. 2000 - Spatial variation in size and age structures and reproductive characteristics of the King Gorge whiting (Percoidi: Sillahinidae) in South Australian waters - Mar. Freshwat. Res. 51: 11-22.

Ganias K., Somarakis S., Machias A., Theodorou A. 2004 Pattern of oocyte development and batch fecundity in the Mediterranean sardine - Fish. Res. 67: 13-23.

Greer Walker M., Witthames P.R., Bautista De Los Santos I. 1994 - Is the fecundity of the Atlantic mackerel (Scomber scombrus: Scombridae) determinate? - Sarsia 79: 13-26.

Hänfling B., Dumpelmann C., Bogutskaya N.G., Brandl R., Brandle M. 2009 - Shallow phylogeographic structuring of Vimba vimba across Europe suggests two distinct refugia during the last glaciation - J. Fish Biol. 75: 2269-2286.

Hilborn R., Walters C.J. 1992 - Quantitative fisheries stock assessment: choice dynamics and uncertainty - Chapman and Hall, New York: 570 p.

Hosseini Kenari S.M., Alam M., Ardalan A.A., Behnaz M. 2010 - Study on biology of reproduction in Vimba vimba (L. 1758) in Kiashahr region - J. Fish. 4: 47-60 (in Persian).

Hunter J.R., Macewicz B.J., Lo N.C.H., Kimbrell C.A. 1992 Fecundity, spawning and maturity of female Dover sole, Microstomus pacificus, with an evaluation of assumptions and precision - Fish. Bull. 90: 101-128.

Jakobsen T., Fogarty M.J., Megrey B.A., Moksness E. 2009 Fish reproductive biology, implications for assessment and management - Wiley Blackwell Scientific Publications, Chichester, UK, 429 p.

Kazancheev E.N. 1981 - Ryby Kaspiiskogo moria: opredelitel' (Classification of Caspian Fishes) - Translated by Shariati A. 1992- Publishing of Iranian Fishery Organization- 171 p. (in Persian).

Kjesbu O.S. 1994 - Time of start of spawning in Atlantic cod (Gadus morhua) females in relation to vitellogenic oocyte diameter, temperature, fish length and condition - J. Fish Biol. 45: 719-735.

Lam T.J. 1983 - Environmental influences on gonadal activity in fish - In: Fish Physiology Volume IX Reproduction Part B (Eds) H.S. Hoar, D.J. Randall, E.M. Donaldson, Academic Press, New York: 65-116

Lowerre-Barbieri S.K., Ganias K., Saborido-Rey F., Murua H., Hunter J.R. 2011 - Reproductive timing in marine fishes: variability, temporal scales, and methods - Mar. Coast. Fish. 3: 71-91.

Łuszczek-Trojnar E., Drąg-Kozak E., Kleszcz M., Popek W., Epler P. 2008 - Gonadal maturity in vimba (Vimba vimba L.) raised in carp ponds - J. Appl. Ichthyol. 24: 316-320.

Marshall C.T., Kjesbu O.S., Yaragina N.A., Solemdal P., Ulltang Ø. 1998 - Is spawner biomass a sensitive measure of the reproductive and recruitment potential of Northeast Arctic cod? - Can. J. Fish. Aqut. Sci. 55: 1766-1783.

Munro A.D., Scott A.P., Lam T.J. 1990 - Reproductive Seasonality in Teleosts: Environmental Influences - Boca Raton, FL: CRC Press. 
Murua H. 2010 - The biology and fisheries of European Hake, Merluccius merluccius, in the North-East Atlantic - In: Advances in Marine Biology (Ed.) M. Lesser, Burlington, Oxford University Press. 58: 97-154.

Murua H., Sabrido-Ray F. 2003 - Female reproductive strategies of marine fish species of the North Atlantic - J. Northw. Atl. Fish. Sci. 33: 23-31.

Narimatsu Y., Kitagawa D., Hattori T., Onodera H. 2005 Reproductive biology of female Rikuzen sole (Dexistes rikuzenius) - Fish. Bull. 103: 635-647.

Okgerman H., Elp M., Yardimci C.H. 2011 - Growth, the length-weight relationship, and reproduction in Vimba (Vimba vimba L.1758) sampled from an oligo-mesotrophic lake in northwest Anatolia (Turkey) Turk. J. Zool. 35: 87-96.

Patimar R. Safari S. 2010 - Description of the biology of Caspian vimba, Vimba vimba (Linnaeus,1758) in Gorgan Bay-Miankaleh Wildlife Refuge (Southeast Caspian Sea) - Chin. J. Oceanol. Limnol. 28: 1173-1179.

Quinn T.J., Deriso R.B. 1999 - Quantitative fish dynamics Oxford University Press, New York, 542 p.

Rinchard J., Kestemont R. 2003 - Liver changes related to oocyte growth in roach a single spawner fish, and in bleak and white bream, two multiple spawner fish - Internat. Rev. Hydrobiol. 88: 68-76.
Schishabekov M.M. 1979 - O biologii razmnozheniya kutuma Rutilus frisii kutum (Kamensky), zherekha Aspius aspius (L.), rybtsa Vimba vimba persa (Pallas) i krasnopierki Scardinus erythrophthalmus (L.) v vodoemakh Dagestana - Vopr. Ikhtiol. 19: 495-502 (in Russian).

Scott S.G., Pankhurst N.W. 1992 - Interannual variation in the reproductive cycle of the New Zealand snapper Pagrus auratus (Sparidae) - J. Fish Biol. 41: 685-696.

Tracey S.R., Lyle J.M. 2005 - Age validation, growth modelling, and mortality estimates for striped trumpeter (Latris lineata) from southeastern Australia: making the most of patchy data - Fish. Bull. 103: 169-182.

Trippel E.A. 1995 - Age at maturity as a stress indicator in fisheries - Bioscience 45: 759-771.

Tyler C.R., Sumpter J.P. 1996 - Oocyte growth and development in teleosts - Rev. Fish. Biol. Fish. 6: 287-343.

Wallace R.A., Selman K. 1981 - The reproductive activity of Fundulus heteroclitus females from Woods Hole, Massachusetts, as compared with more southern locations Copeia 1: 212-215.

Wootton R.J. 1982 - Environmental factors in fish reproduction - In: Reproductive Physiology of Fish (Eds) C.J.J. Richter, H.J.T. Goss, Pudoc, Wageningen, NL: 201-219. 